\title{
D Vitamini Eksikliği Olan Yetişkinlerde Paraoksonaz ve Arilesteraz Aktiviteleri
}

\author{
Paraoxonase and Arylesterase Activities In Adults with Vitamin D Deficiency
}

Filiz Alkan Baylan, Metin Kılınç, Yeliz Dobooğlu, Hatice Sağer

Kahramanmaraş Sütçü Imam Üniversitesi Tip Fakültesi Biyokimya AD.

Yazışma Adresi / Correspondence:

Filiz Alkan Baylan

Sütçü İmam Üniversitesi, Tip Fakültesi, Tibbi Biyokimya Ana Bilim Dalı, Kahramanmaraş

T: $+905444704328 \quad$ E-mail : drfilizalkan@gmail.com

Geliş Tarihi / Received : 12.04.2021 Kabul Tarihi / Accepte: 05.07.2021

Orcid :

Filiz Alkan Baylan https://orcid.org/0000-0003-3117-7768

Metin Kılınç https://orcid.org/0000-0002-1623-0201

Yeliz Dobooğlu https://orcid.org/0000-0001-5874-0368

Hatice Sağer https://orcid.org/0000-0002-5937-6884

( Sakarya Tip Dergisi / Sakarya Med J 2021, 11(3):571-575) DoI: 10.31832/smj.913255

\footnotetext{
$\ddot{O} \mathrm{z}$

Amaç Bu çalıșmanın amacı, D vitamini eksikliği olan erişkinlerde oksidatif stres ve kardiyovasküler hastalıklar için risk belirteci olan Paroksonaz (PON), Arilesteraz (ARE) ve Lipoprotein a (Lp (a)) düzeylerini değerlendirmektir.

Gereç ve Çalışmaya D vitamini eksikliği olan 43 hasta ve benzer demografik özelliklere sahip olan 37 sağlıklı birey dahil edildi. 25 (OH) D'nin $20 \mathrm{ng} / \mathrm{mL}$ ' nin altında olması D Yöntemler vitamini eksikliği olarak kabul edildi. Gruplar arasında PON-1, ARE enzim aktiviteleri, Lp (a) ve serum lipid düzeyleri karşıllaștırıldı.

Bulgular D vitamini eksikliği olan hastalarda PON aktivitesi sağlıklı kontrol grubuna göre düşük bulundu. Gruplar arasında ARE aktivitesi ve Lp (a) benzer düzeylerdeydi. D vitamini ile PON arasında pozitif yönde bir ilişki gözlemlendi.

Sonuç D vitamini eksikliği olan grup daha düşük PON-1 aktivitesine sahipti. D vitamini eksikliğinin neden olduğu oksidatif stres artışına, LDL düzeylerindeki artış ve HDL düzeyindeki azalma ile birlikte PON-1 aktivitesinin düșüklüğünün neden olabileceği düșünüldü.

Anahtar D vitamini; Paroksonaz; Arilesteraz; Lipoprotein a

Kelimeler

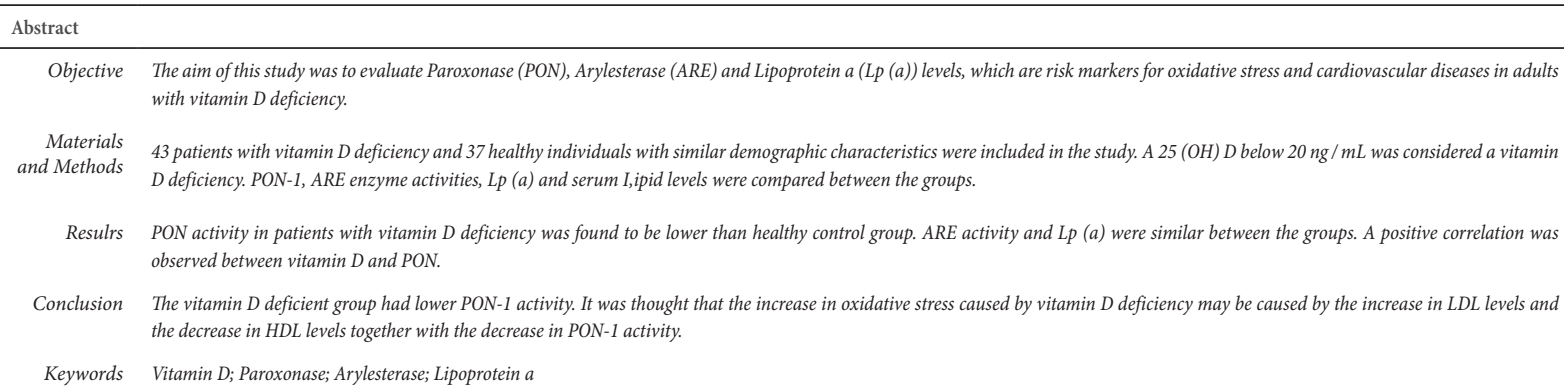




\section{GIIRIŞ}

D vitamini, bir steroid hormon yapısında, yağda çözünen bir vitamindir. Mineral homeostazisinde ve iskelet sisteminde önemli rollere sahiptir. Son yıllarda çeşitli önemli fonksiyonlarının ortaya konmasından sonra D vitamin eksikliğinin (<20 ng/ml) küresel boyutta bir sağlık problemi olarak karşımıza çıktığı görülmektedir. ${ }^{1} \mathrm{D}$ vitamini eksikliği raşitizm, osteomalazi, osteoporoz gibi kemik hastalıklarının yanında deri hastalıkları, kanser, otoimmün hastalıklar ve kardiyovasküler hastalıklar gibi patolojik durumlarla ilişkilendirilmiştir. ${ }^{2-5}$ Pek çok çalışmada, düşük D vitamini ile kardiyovasküler hastalık arasındaki ilişkinin, D vitamininin lipid düşürücü etkisiyle ilişkili olduğu savunulmuştur. ${ }^{6-8}$ Aynı zamanda D vitamininin oksidatif strese karşı koruyucu etkisinin olduğu bilinmektedir., ${ }^{910}$ Paraoksonaz 1 (PON1), detoksifikasyon dahil önemli fizyolojik fonksiyonlara sahip yüksek yoğunluklu lipoprotein (HDL) kolesterole bağlı bir enzimdir. Antioksidan özelliklere sahiptir ve karaciğer tarafından sentezlenir. PON1; PON, diazoksonaz ve arilesteraz (ARE) aktivitelerine sahip çok işlevli bir enzimdir. PON1 enzimi, makrofajlardan superoksit anyon salınımını inhibe ederek LDL oksidasyonunu önler ve okside-LDL (oxLDL) oluşumunu azaltır. Böylece endotel hücrelerde oxLDL' ye bağlı oluşan inflamasyon süreci engellenmiş olur. ${ }^{11}$ Lipoprotein a (Lp (a)) konsantrasyonları farklı etnik popülasyonlarda büyük ölçüde değişiklik gösterse $\mathrm{de}^{12}$, koroner kalp hastalıkları için bağımsız bir risk faktörü olduğu gösterilmiştir. ${ }^{13,14}$

$D$ vitamini eksikliği olan hastalarda $P O N$ ve ARE düzeyi, bu tür eksiklikte yer alan altta yatan biyokimyasal mekanizmaları netleștirmeye yardımcı olabilir. $\mathrm{Bu}$ çalışmanın amac1, D vitamini eksikliği olan erişkinlerde PON ve ARE enzim aktivitelerini araştırmak, D vitamini eksikliğinin oksidatif stres ve kardiyovasküler hastalıklar için risk belirteci olan PON-1, ARE ve Lp (a) üzerindeki etkilerini değerlendirmektir.

\section{GEREÇ ve YÖNTEMLER}

Çalışmamıza D vitamini eksikliği olan 43 hasta ve benzer demografik özelliklere sahip olan 37 sağlıklı birey dahil edildi. Serum 25-hidroksivitamin D [25 (OH) D] seviyeleri Mart-Eylül ayları arasında ölçüldü. $25(\mathrm{OH})$ D’nin 20 ng/mL' nin altında olması D vitamini eksikliği olarak kabul edildi. Bilinen kardiyovasküler, serebrovasküler hastalığı, konjestif kalp yetmezliği, akut ya da kronik karaciğer hastalığı, her hangi bir malignitesi, diyabeti olan hastalar ile gebeler, sigara ve alkol kullananlar, D vitamini kullananlar, D vitaminin metabolizması üzerine etki eden lipid ya da glikoz metabolizması üzerine etki eden ilaç kullanımı olanlar çalışmadan dışlandı. Çalışma Kahramanmaraş Sütçü İmam Üniversitesi Tip Fakültesi etik kurulu tarafından 14.10.2020 tarih ve 2/357 karar numarası ile onaylandı. Tüm katılımcılardan bilgilendirilmiş onam alındı.

Araştırmaya dahil olan bireylerden en az sekiz saatlik açlık süresi sonrasında rutin tetkikleri için eş zamanlı olarak $10 \mathrm{~mL}$ kan alındı. Örnekler $4^{\circ} \mathrm{C}$ 'de $2500 \mathrm{rpm}$ devirde 10 dakika santrifüj edilerek serum ayrıldı. EDTA’lı tüplere alınan kandan ayrılan plazmada $25-\mathrm{OH} \mathrm{D}$ vitamini Thermo scientific ultimate 3000 cihazında (Mundelein, USA) ultra HPLC ölçüm yöntemi ile ölçüldü. PON, ARE ve Lp (a) ölçümü için ayrılan serumlar çalışma zamanına kadar $-80^{\circ} \mathrm{C}$ 'de saklandı. PON ve ARE (Rel Assay Diagnostic, Mega Tip, Gaziantep, Turkey) ticari kit kullanılarak kolorimetrik prensiple otomatik analizörde, Lp (a) ise ELISA (Enzyme-Linked Immunosorbent Assay) (Rel Assay Diagnostic, Mega Tip, Gaziantep, Turkey) ticari kitleri ile kit prosedürlerine uygun şekilde ölçüldü. Serum lipid (total kolesterol, LDL, HDL ve trigliserid) düzeyleri ise fotometrik yöntemle Roche Cobas C702 cihazında ölçüldü.

Verilerin değerlendirilmesinde değişkenlerin normal dağılıma uygunluğu Shapiro-Wilk testi ile incelendi. Normal dağılım gösteren değişkenlerde 2 grup karşılaştırmaları Student T-Testi, göstermeyen değişkenlerde 2 grup karşılaştırmaları Mann-Whitney U testi ile gerçekleştirildi. Parametreler arasındaki ilişki Spearman korelasyon analizi ile değerlendirildi. İstatistiksel anlamlılık $\mathrm{p}<0.05$ olarak kabul edildi. İstatistik parametreleri Median (min-max) 
ve ortalama \pm standart sapma olarak ifade edildi. Veriler IBM SPSS Statistics for Windows (IBM SPSS for Windows version 22, IBM Corparation, Armonk, New York, United States) ile değerlendirildi.

\section{BULGULAR}

Çalışmadaki D vitamini eksikliği grubunun medyan yaşı 37, kontrol grubunun ise 39 idi. Gruplar arasında yaş ve cinsiyetleri açısından anlamlı bir fark yoktu (sırasıyla $\mathrm{p}=0,689, \mathrm{p}=0,241$; Tablo 1). PON-1 değerleri $\mathrm{D}$ vitamini

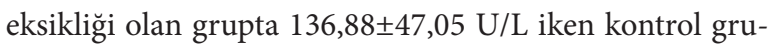
bunda 198,04 $\pm 69,80 \mathrm{U} / \mathrm{L}$ olmak üzere aradaki fark istatistiksel olarak anlamlıydı. ( $\mathrm{p}<0,001$; Tablo 2, Şekil 1). ARE ve $\operatorname{Lp}$ (a) değerleri ise hasta ve kontrol grupları arasında anlamlı farklılık göstermedi (sırasıyla $\mathrm{p}=0,060, \mathrm{p}=0,079$; Tablo 2). Total Kolesterol ve LDL düzeyleri D vitamini eksikliği grubunda yüksek iken ( $\mathrm{p}<0,001$; Tablo 2). HDL düzeyleri düşük bulundu ( $\mathrm{p}=0,042$; Tablo 2).

\begin{tabular}{|c|c|c|c|}
\hline Özellikler & $\begin{array}{l}\text { D Vitamini } \\
\text { Eksikliği Olan Grup } \\
\qquad(\mathrm{n}=43)\end{array}$ & $\begin{array}{l}\text { Kontrol Grubu } \\
\qquad(\mathrm{n}=37)\end{array}$ & $\mathrm{p}$ \\
\hline Yaş (yıl) & $37(20-66)$ & $39(16-69)$ & $0,689^{*}$ \\
\hline \multicolumn{4}{|c|}{ Cinsiyet n, (\%) } \\
\hline Erkek & $7(16.3)$ & $10(27)$ & \multirow{2}{*}{$0,241 \dagger$} \\
\hline Kadın & $36(83.7$ & $27(73)$ & \\
\hline \multicolumn{4}{|c|}{$\begin{array}{l}{ }^{*} \text { Mann-Whitney U test. (Değerler medyan(minumum-maksimum) olarak } \\
\text { ifade edildi.) } \\
\dagger \text { Chi-square test }\end{array}$} \\
\hline
\end{tabular}

Çalışmada D vitamini ile PON arasında zayıf düzeyde pozitif yönlü bir ilişki vardı $(r=0,351, p=0,001)$. D vitamini ile Total kolesterol arasında orta düzeyde negatif bir ilişki varken $(r=-0.508, p<0,001) D$ vitaminin ile LDL arasında zayıf düzeyde negatif bir ilişki vardı. $(r=-0,347, p=0,002$ sırayla) (Tablo 3 ).

\begin{tabular}{|l|c|c|c|}
\hline Tablo 2. Hasta ve Kontrol Gruplarının Laboratuvar Sonuçları \\
\hline $\begin{array}{l}\text { Laboratuvar Para- } \\
\text { metreleri }\end{array}$ & $\begin{array}{c}\text { D Vitamini } \\
\text { Eksikliği olan grup } \\
(\mathrm{n}=43)\end{array}$ & $\begin{array}{c}\text { Kontrol grubu } \\
(\mathrm{n}=37)\end{array}$ & $\mathrm{p}$ \\
\hline $\begin{array}{l}25(\mathrm{OH}) \mathrm{D} \text { vitamini } \\
(\mathrm{ng} / \mathrm{mL})\end{array}$ & $\begin{array}{c}8,72 \\
(3,00-19,00)\end{array}$ & $\begin{array}{c}27,00 \\
(21,00-88,00)\end{array}$ & $<0,001^{*}$ \\
\hline $\begin{array}{l}\text { Total } \\
\text { Kolesterol (mg/dL) }\end{array}$ & $190,00 \pm 24,61$ & $158,32 \pm 12,57$ & $<0,001^{*}$ \\
\hline LDL (mg/dL) & 128,00 & 95,00 & $<0,001^{*}$ \\
\hline HDL (mg/dL) & $55,00 \pm 6,83$ & $59,00 \pm 9.37$ & $0,042^{*}$ \\
\hline TG (mg/dL) & $129,44 \pm 41,15$ & $118,73 \pm 42,33$ & 0,255 \\
\hline PON (U/L) & $136,88 \pm 47.05$ & $198,04 \pm 69,80$ & $<0,001^{*}$ \\
\hline ARE (U/L) & $70,79 \pm 16,29$ & $63,55 \pm 17,71$ & 0,060 \\
\hline $\begin{array}{l}\text { Lp (a) } \\
(\mathrm{mg} / \mathrm{dL})\end{array}$ & $7,94(4,59-15,20)$ & $7,35(2,18-10,08)$ & 0,079 \\
\hline
\end{tabular}

Sayısal değişkenler, normallik dağılımına göre ortalama \pm standart sapma veya medyan (min-maks) olarak ifade edildi.

Mann Whitney U testi/Student t Testi: $\alpha: 0.05 ;{ }^{*}$ Anlamlı LDL; Düşük-Dansititeli Lipoprotein, HDL; Yüksek-Densititeli Lipoprotein, TG; Trigliserid, PON; Paroksonaz-1, ARE; Arilesteraz, Lp (a) ; Lipoprotein a

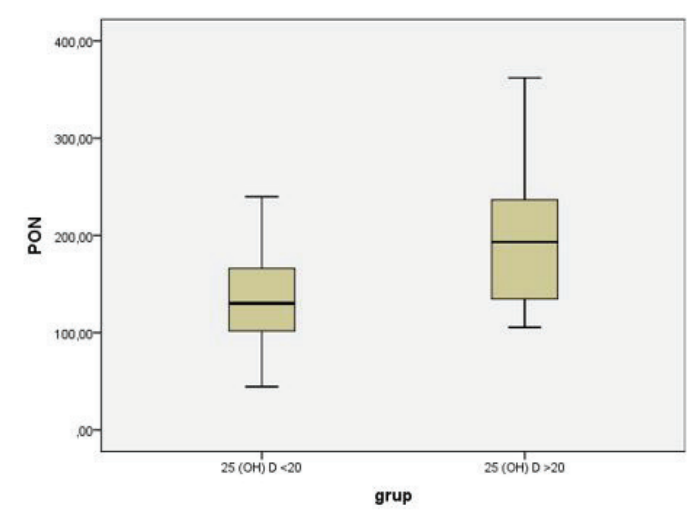

Şekil 1. Çalışma Gruplarının Paraoksonaz Seviyeleri

\begin{tabular}{|l|c|c|}
\hline \multicolumn{2}{|c|}{ Tablo 3. D Vitamini ile Diğer Parametreler Arasındaki İlişki } \\
\hline & $25(\mathrm{OH}) \mathrm{D}$ Vitamini (ng/mL) \\
\hline & $\mathrm{r}$ & $\mathrm{p}$ \\
\hline $\begin{array}{l}\text { Total Kolesterol (mg/ } \\
\text { dL) }\end{array}$ & $-0,508$ & $<0,001^{*}$ \\
\hline LDL (mg/dL) & $-0,347$ & $0,002^{*}$ \\
\hline HDL (mg/dL) & 0,131 & 0,248 \\
\hline TG (mg/dL) & $-0,030$ & 0,791 \\
\hline PON (U/L) & 0,351 & $0,001^{*}$ \\
\hline ARE (U/L) & $-0,096$ & 0,396 \\
\hline Lp (a) (mg/dL) & $-0,148$ & 0,191 \\
\hline $\begin{array}{l}\text { r; Spearman'in rho korelasyon katsayıs1. } \\
\text { LDL; Düşük-Dansititeli Lipoprotein, HDL; Yüksek-Densititeli Lipoprotein, } \\
\text { TG; Trigliserid, PON; Parok-sonaz-1, ARE; Arilesteraz, Lp (a) ; Lipoprotein } \\
\text { a }\end{array}$
\end{tabular}




\section{TARTIŞMA}

Bu çalı̧mada D vitamini durumu ile PON, ARE, Lp (a) ve lipid düzeyleri arasındaki ilişkiyi araştırmayı amaçladık. D vitamini eksikliği olan hastalarda PON aktivitesi sağlıklı kontrol grubuna göre düşük iken ARE aktivitesi benzerdi. Gruplar arasında Lp (a) düzeyleri de benzerdi. D vitamini ile PON arasında pozitif bir ilişki gözlemledik.

Oksidatif stresin bir göstergesi olan PON enzimi, LDL oksidasyonunu inhibe eder ve kardiyovasküler hastalıklara karşı korur. ${ }^{15,16} \mathrm{Bu}$ enzimin aktivitesi, oksidatif stresin artmasıyla azalır. ${ }^{17}$ Tarcın ve arkadaşları D hipovitaminozunda PON aktivitesi ile endotel fonksiyonu arasindaki ilişkiyi incelemiştir. Bu çalı̧̧mada D vitamini tedavisi sonrası PON aktivitesinde bir değişiklik olmasa da, PON aktivitesi ile endotel fonksiyonu arasındaki pozitif korelasyon nedeniyle D vitamininin oksidatif stresi azalttığı savunulmuştur. ${ }^{18} \mathrm{D}$ vitamini tedavisinden sonra $\mathrm{PON}$ ve ARE aktivitelerinde önceki değerlerle herhangi bir değişiklik saptanmadığını belirten çalışmalar da mevcuttur. ${ }^{19}$ Bizim yaptığımız çalışmada daha önceki çalışmaların aksine D vitamini eksikliği olan hastalarda düşük PON-1 seviyeleri ve ayrıca D vitamini ile PON-1 arasında pozitif bir ilişki olduğunu gözlemledik. Daha önce D vitamini takviyesi ile yapılan randomize çalışmalardan elde edilen ilgili bulgular, muhtemelen küçük örnek boyutları, nüfus özelliklerindeki farkllılklar, D vitamini takviyesinin süresi, dozu ve formülasyonu nedeniyle çelişkili olacağı düşünülebilir. Yapılan bir çalışmada normal D vitamini düzeyine sahip olanlara göre $\mathrm{D}$ vitamini hipovitaminozu olan tip 2 diyabetik hastalarda serum okside-LDL seviyelerinin anlamlı derecede daha yüksek olduğu belirtilmiştir. ${ }^{20}$ Plazma lipoproteinleri ile D vitamini iliş̧kisini araştırma amaçlı yapılan bir çalışmada da düşük D vitamini; yüksek trigliserid ile ilişkili bulunmuş, total kolesterol, LDL ve HDL düzeyleri açısından D vitamini eksikliği olan grup ile olmayan grup arasında fark bulunamamıştır. ${ }^{21} \mathrm{Bu}$ konuda yapılan bir diğer çalışmada da yine D vitamini $<25 \mathrm{ng} / \mathrm{mL}$ olan grupta yüksek total kolesterol, trigliserid, LDL ve düşük HDL saptanmıştır. ${ }^{22} \mathrm{Bu}$ çalışmalara benzer şekilde olarak biz de çalışmamızda D vitamini eksikliği olan hasta grubunda daha yüksek total kolesterol ve LDL, daha düşük HDL seviyeleri tespit ettik. HDL seviyesindeki bu düşüklük, HDL' ye bağlı bir enzim olan PON-1 aktivitesindeki azalmayı açıklayabilir. D vitamini takviyesi alımından sonra plazma Lp (a) seviyesinde azalma görmüşlerdir. ${ }^{23}$ $\mathrm{Bu}$ çalışmanın aksine Qoi ve arkadaşları D vitamini ile Lp (a) arasında bir ilişki bulamamışlardır. Lp (a) referans değerleri arasındaki farkın fazla olması dolayısıyla patolojik durumlarda değerlendirmenin kolay olmadığı görülmektedir. ${ }^{24}$ Çalışmamızın bulguları Qoi ve arkadaşlarının çalışmasındaki bulguları destekler nitelikteydi.

D vitamin düzeyini etkileyebilecek değişik faktörlerin önemli olduğu da bilinmektedir. Bunlar; güneșe maruz kalmama, yetersiz beslenme, cilt rengi, güneş kremi kullanımı, örtülü giysiler, obezite, beslenme alışkanlıkları ve D vitamini takviyesi geçmişi gibi diğer faktörlerdir ve bunlar tarafımızdan değerlendirilemedi.

Sonuç olarak, bu çalışmada, D vitamini eksikliği olan erişkinlerde antioksidan enzimlerden PON-1 aktivitesi kontrollere göre düşük bulunurken, ARE aktivitesinde ve serum Lp (a) düzeylerinde bir değişiklik saptanmamıştır. İleride daha geniş bir çalışma grubu ile çalışmanın planlanması ayrıca $D$ vitamini takviyesi verilip takviye öncesi ve sonrası alınan plazmada $D$ vitamini, PON, ARE ve Lp (a) 'nın ölçümü ile desteklenmesi gerektiğine inanılmaktadir. 
Sakarya Tip Dergisi 2021;11(3):571-575

BAYLAN ve Ark., D Vitamin Eksikliğinde Paraoksonaz ve Arilesteraz Aktiviteleri

\section{Kaynaklar}

1. Palacios C, Gonzalez L. Is vitamin D deficiency a majör global public health problem? J Steroid Biochem Mol Biol 2014;144:138-145.

2. Holick MF. Vitamin D deficiency. N Engl J Med. 2007;357(3):266-281.

3. Wadhwa B, Relhan V, Goel K, Kochhar AM, Garg VK. Vitamin D and skin diseases: A review. Indian J Dermatol Venereol Leprol. 2015;81(4):344-355.

4. Rai V, Agrawal DK. Role of Vitamin D in Cardiovascular Diseases. Endocrinol Metab Clin North Am. 2017;46(4):1039-1059. doi:10.1016/j.ecl.2017.07.009.

5. Christakos S, Dhawan P, Verstuyf A, Verlinden L, Carmeliet G. Vitamin D: Metabolism, Molecular Mechanism of Action And Pleiotropic Effects. Physiol Rev. 2016;96:365-408.

6. Jorde R, Grimnes G. Vitamin D and metabolic health with special reference to the effect of vitamin D on serum lipids. Prog Lipid Res. 2011;50:303-312.

7. Martins D, Wolf M, Pan D, Zadshir A, Tareen N, Thadhani R, et al. Prevalence of cardiovascular risk factors and the serum levels of 25-hydroxyvitamin D in the United States: data from the Third National Health and Nutrition Examination Survey. Arch Intern Med. 2007;167:1159-1165.

8. Zittermann A, Gummert JF, Börgermann J. The role of vitamin D in dyslipidemia and cardiovascular disease. Curr Pharm Des. 2011;17:933-942.

9. Dong J, Wong SL, Lau CW, Lee HK, $\mathrm{Ng} C F$, Zhang L, et al. Calcitriol protects renovascular function in hypertension by downregulating angiotensin II type 1 receptors and reducing oxidative stress. Eur Heart J [Internet]. 2012;33(23):2980-2990. Available from: http:// www.ncbi.nlm.nih.gov/pubmed/22267242

10. Berridge MJ. Vitamin D cell signalling in health and disease. Biochem Biophys Res Commun [Internet]. 2015;460(1):53-71. Available from: http://dx.doi.org/10.1016/j. bbrc.2015.01.008

11. White CR, Anantharamaiah GM. Cholesterol Reduction and Macrophage Function: Role of Paraoxonases. Curr Opin Lipidol. 2017;28(5):397-402. doi:10.1097/ MOL.0000000000000444

12. Kronenberg F. Prediction of cardiovascular risk by $L p(a)$ concentrations or genetic variants within the LPA gene region. Clin Res Cardiol Suppl. 2019;14(S1):5-12. doi: 10.1007/s11789019-00093-5.

13. Katsiki N, Al-Rasadi K, Mikhailidis DP. Lipoprotein (a) and Cardiovascular Risk: The Show Must go on. Curr Med Chem. 2017;24(10):989-1006. doi: 10.2174/092986732466617011 2111948.
14. Orsó E, Schmitz G. Lipoprotein(a) and its role in inflammation, atherosclerosis and malignancies. Clin Res Cardiol Suppl. 2017;12:31-37.

15. Kowalska K, Socha E, Milnerowicz M. Review: The role of paraoxonase in cardiovascular diseases. Ann Clin Lab Sci. Spring. 2015;45(2):226-233.

16. Chistiakov, DA, Melnichenko, AA, Orekhov AN, \& Bobryshev YV. Paraoxonase and atherosclerosis-related cardiovascular diseases. Biochimie. 2017;132:19-27. doi:10.1016/j. biochi.2016.10.010.

17. Azarsiz E, Kayikcioglu M, Payzin S, Yildirim Sözmen E. PON1 activities and oxidative markers of LDL in patients with angiographically proven coronary artery disease. Int J Cardiol. 2003;91(1):43-51.

18. Tarcin O, Yavuz DG, Ozben B, Telli A, Ogunc AV, Yuksel M, et al. Effect of vitamin D deficiency and replacement on endothelial function in asymptomatic subjects. J Clin Endocrinol Metab. 2009;94(10):4023-4030. doi: 10.1210/jc.2008-1212.

19. Makariou SE, Elisaf M, Challa A, Tellis C, Tselepis AD, Liberopoulos EN. Effect of combined vitamin $D$ administration plus dietary intervention on oxidative stress markers in patients with metabolic syndrome: A pilot randomized study. Clin Nutr ESPEN. 2019;29:198-202. doi:10.1016/j.clnesp.2018.10.004.

20. Javanbakht MH, Mohammady H, Fooladsaz K, Razzaghi M, Zarei M, Djalali M. Are serum levels of F2-isoprostane and oxidized-LDL related to vitamin D status in type 2 diabetic patients? A case-control study. Rep Biochem Mol Biol. 2016;5:26-32.

21. Kim MR, Jeong SJ. Relationship between Vitamin D Level and Lipid Profile in Non-Obese Children. Metabolites. 2019 Jun 30;9(7):125.

22. Yarparvar A, Elmadfa I, Djazayery A, Abdollahi Z, Salehi F. The Association of Vitamin D Status with Lipid Profile and Inflammation Biomarkers in Healthy Adolescents. Nutrients. 2020;12(2):590. doi: 10.3390/nu12020590.

23. Shab-Bidar S, Neyestani TR, Djazayery A, Eshraghian MR, Houshiarrad A, Gharavi A, et al. Regular consumption of vitamin D-fortified yogurt drink (Doogh) improved endothelial biomarkers in subjects with type 2 diabetes: a randomized double-blind clinical trial. BMC Med. 2011;9:125. doi: 10.1186/1741-7015-9-125.

24. Ooi EM, Afzal S, Nordestgaard BG. Elevated remnant cholesterol in 25-hydroxyvitamin $D$ deficiency in the general population: Mendelian randomization study. Circ Cardiovasc Genet. 2014;7(5):650-658. 